\title{
Chronic Electroconvulsive Seizure (ECS) Treatment Results in Expression of a Long-lasting AP-1 Complex in Brain with Altered Composition and Characteristics
}

\author{
Bruce T. Hope, Max B. Kelz, Ronald S. Duman, and Eric J. Nestler \\ Laboratory of Molecular Psychiatry, Departments of Psychiatry and Pharmacology, Yale University School of Medicine, \\ and Connecticut Mental Health Center, New Haven, Connecticut 06508
}

Gene transcription is likely to play a role in the biochemical adaptations thought to underlie the long-term behavioral changes observed following various chronic treatments. The AP-1 (activator protein-1) complex is a well-studied transcription factor capable of regulating gene transcription. We therefore examined the regulation of the AP-1 complex in rat cerebral cortex and hippocampus following electroconvulsive seizures (ECS), known to induce biochemical alterations in the brain after chronic treatment. We show that 10 d of chronic ECS treatment results in an AP-1 binding complex that persists for at least $7 \mathrm{~d}$ in the cortex and hippocampus. In contrast, AP-1 binding returns to control levels within $18 \mathrm{hr}$ of a single acute ECS. Supershift experiments and Western blots show that the chronic AP-1 complex contains two novel Fos-related antigens (Fras) of 35 and $37 \mathrm{kDa}$ that do not appear following a single acute ECS. The chronically induced 35 and $37 \mathrm{kDa}$ Fras and the chronic AP-1 complex show similar time courses for induction by repeated ECS. Moreover, the $37 \mathrm{kDa}$ Fra band persists for at least 7 d following chronic ECS treatment, as observed for the chronic AP-1 complex. Competition experiments indicate that the relative affinities of the acute and chronic AP-1 complexes for several AP-1-like sites are similar, although there was approximately a twofold difference in the affinity for one particular AP-1-like site. The altered composition of the chronic AP- 1 complex, and differences in half-life, DNA binding affinity, and possibly transcriptional activating properties are likely to cause changes in the overall pattern of gene expression, which may underlie some of the long-term biochemical adaptations observed following chronic ECS and other chronic perturbations.

[Key words: AP-1, transcription factor, gene expression, Fos, electroconvulsive seizures (ECS), Fos-related antigen (Fra), DNA binding protein]

Long-term biochemical adaptations are thought to underlie the efficacy of chronic antidepressant and antipsychotic treatments, as well as addiction induced by drugs of abuse. The changes observed following chronic treatments are different from, and

Received Aug. 4, 1993; revised Dec. 28, 1993; accepted Jan 13, 1993.

This work was funded by USPHS Grants DA07359, MH45481, and MH25642, and by the Abraham Ribicoff Research Facilities of the Connecticut Mental Health Center, State of Connecticut Department of Mental Health.

Correspondence should be addressed to Eric J. Nestler at the above address

Copyright (C) 1994 Society for Neuroscience $0270-6474 / 94 / 144318-11 \$ 05.00 / 0$ often oppose, those following acute treatments, suggesting that different mechanisms may predominate. Since a number of the changes following chronic treatments include long-term alterations at the mRNA level (see Hyman and Nestler, 1993), it is likely that control of gene expression plays an important role in the adaptation of neurons to chronic perturbations.

Gene expression is influenced by drug treatments and extracellular stimuli via regulation of transcription factors and associated proteins. Several of the most studied transcription factors are encoded by immediate-early genes (IEGs), including c-fos (for review, see Morgan and Curran, 1991). c-fos and other IEGs can be induced rapidly via several different second messenger systems and are thought to mediate some of the effects of extracellular stimuli on subsequent changes in gene expression (Morgan and Curran, 1991; Bading et al., 1993; Lerea and McNamara, 1993). The induced c-Fos protein produces its effect by forming heterodimers with another IEG protein product, c-Jun, to form an AP-1 (activator protein-1) complex. The AP-1 complex binds specifically to an AP-1 site, which has the DNA consensus sequence TGAG/CTCA, in the promoter region of a gene to activate or repress gene transcription. Many neurobiologically important genes contain putative AP-1 sites in their promoter regions, including those for tyrosine hydroxylase (Yoon and Chikaraishi, 1992), $D_{1}$ dopamine receptor (Zhou et al., 1992), NGF receptor (D'Mello and Heinrich, 1991), RII $\beta$ subunit of protein kinase A (Singh et al., 1991), neurofilament-H (Shneidman et al., 1992), and neurotensin/neuromedin N (Dobner et al., 1991).

One possible way by which chronic treatments could regulate AP-1-mediated transcription is to alter the composition of the AP-I complex. In vitro studies have shown that there are a large number of Fos-related proteins, called Fras (Fos-related antigens), also capable of dimerizing with c-Jun to form AP-1 complexes (Cohen et al., 1989; Morgan and Curran, 1991; Dobrzanski et al., 1991). A few of these Fras have been identified, including Fra-1, Fra-2, FosB, and its truncated form, called $\Delta$ FosB (Busch and Sassone-Corsi, 1990; Mumberg et al., 1991). Additionally, there are many Jun-related proteins, including JunB and JunD (Nakabeppu et al., 1988). Unlike c-Fos and Fras, the Jun-related proteins can homodimerize to form active AP- 1 complexes (Angel et al., 1988). This large number of potential dimer combinations would allow for a large variety of AP-1 complexes, with different DNA binding characteristics, half-lives, and transcription regulatory properties. This is in addition to the posttranslational effects of phosphorylation on the above proteins (e.g., Curran et al., 1987; Angel et al., 1988; Ofir et al., 1990; Abate 
et al., 1991; Hunter and Karin, 1992; Papavassiliou et al., 1992; Taylor et al., 1993), which would allow for even greater diversity in the regulation of AP-1-dependent genes in response to a changing cellular environment.

In vivo studies have shown that a single acute seizure results in the induction of c-Fos and a cascade of Fras that change the composition of AP-1 over a period of several hours (Sonnenberg et al., 1989). Similar changes have been observed in the caudate nucleus following a single acute cocaine treatment (Young et al., 1991). Chronic in vivo treatments can lead to further changes, including changes in the expression of certain IEGs and in the duration of increases in AP-1 binding activity. Chronic administration of electroconvulsive seizures (ECS) decreases the ability of a subsequent ECS to induce c-Fos and c-Jun in cerebral cortex (Winston et al., 1990). Chronic cocaine treatment produces a similar desensitization in the ability of a subsequent cocaine injection to induce these and related IEGs in the nucleus accumbens (Hope et al., 1992). Moreover, the cocaine-induced desensitization is associated with a persistent elevation of AP-1 binding activity: AP-1 binding induced by acute cocaine returns to control levels $8-12 \mathrm{hr}$ later, whereas that induced by chronic cocaine persists for at least $72 \mathrm{hr}$ (Hope et al., 1992). Chronic cocaine treatment may therefore result in the induction of an AP-1 complex of altered composition and half-life.

We have now characterized a similarly long-lasting AP-1 complex in rat cerebral cortex and hippocampus following chronic ECS. The AP- 1 complex persists for up to $7 \mathrm{~d}$ following cessation of chronic ECS treatment and contains apparently novel forms of Fras, which we have designated chronic Fras. These proteins could underlie some of the long-term biochemical changes observed in the brain following chronic ECS treatment, and could be part of a more general mechanism by which other chronic treatments, which acutely induce the AP-1 complex, regulate gene expression.

\section{Materials and Methods}

Animal treatments. Male Sprague-Dawley rats (150-250 gm; Camm Research Institute, Wayne, NJ) were used for all experiments. ECS was administered, as before (Winston et al., 1990), via earclip electrodes $(40 \mathrm{~mA}, 0.3 \mathrm{sec})$. Chronic and chronic+acute animals received a single ECS daily for $10 \mathrm{~d}$. The control and acute animals received chronic sham treatment where electrodes were clipped onto the rats' ears but no current was applied. On day 11 , acute and chronic + acute animals were given an acute ECS, and control and chronic animals were given sham treatment. The rats were killed $2 \mathrm{hr}$ later, as this time was shown to maximally induce c-Fos protein and AP-1 binding. For the acute time course experiments, rats received a single ECS following $5 \mathrm{~d}$ of sham treatment and were killed at varying times thereafter. Prior sham treatments were used to reduce the effects of stress (see Campeau et al., 1991; Sharp et al., 1991).

Gel shift assay. The gel shift assay was performed as before (Hope et al., 1992). Dorsal parietal and prefrontal cortex and hippocampus were obtained by gross dissection and homogenized with Dounce homogenizers in $20 \mathrm{vol}$ of the EMSA buffer of Korner et al. (1989): $20 \mathrm{~mm}$ HEPES, pH 7.9, 0.4 м NaCl, 20\% glycerol, 5 mм $\mathrm{MgCl}_{2}, 0.5$ mм EDTA, $0.1 \mathrm{~mm}$ EGTA, $1 \%$ Nonidet P-40, $10 \mu \mathrm{g} / \mathrm{ml}$ leupeptin, $0.1 \mathrm{~mm}$-aminobenzamidine, $1 \mu \mathrm{g} / \mathrm{ml}$ pepstatin, $0.5 \mathrm{~mm}$ PMSF, $5 \mathrm{~mm}$ DTT. The homogenates were incubated on ice for $30 \mathrm{~min}$ before centrifugation at $15,000 \times \mathrm{g}$ for $20 \mathrm{~min}$ at $4^{\circ} \mathrm{C}$. The supernatant protein $(20 \mu \mathrm{g})$ was incubated at $20^{\circ} \mathrm{C}$ for $20 \mathrm{~min}$ with $1 \mu \mathrm{g}$ of poly $(\mathrm{dI}-\mathrm{dC}) \cdot \operatorname{poly}(\mathrm{dI}-\mathrm{dC}), 40$ $\mu \mathrm{g}$ of bovine serum albumin, $10 \mathrm{~mm}$ Tris- $\mathrm{HCl}, \mathrm{pH} 7.9,10 \mathrm{~mm} \mathrm{KCl}$, mм EDTA, 4\% glycerol, and $1 \mathrm{ng}$ of the radioactively labeled AP-1 probe. The samples were incubated for $20 \mathrm{~min}$ at $20^{\circ} \mathrm{C}$ and electrophoresed at $150 \mathrm{~V}$ for $2 \mathrm{hr}$ in a nondenaturing $6 \%$ acrylamide $/ 0.16 \% N, N^{\prime}$ methylenebisacrylamide gel containing $25 \mathrm{~mm}$ Tris-borate buffer, $\mathrm{pH}$ $8.3,1 \mathrm{~mm}$ EDTA, $1.6 \%$ glycerol. The gels were dried and exposed to $\mathrm{x}$-ray film. Levels of AP-1 binding were quantified by measuring the

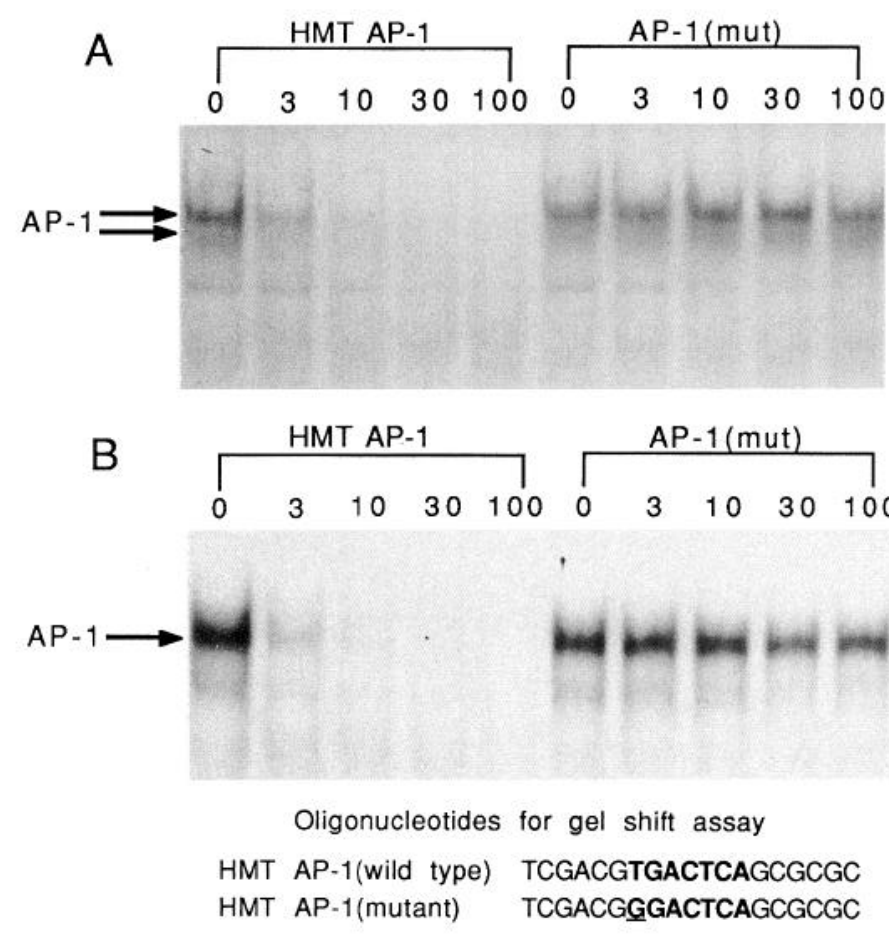

Figure 1. Autoradiogram of a competition experiment showing specific bands of AP-1 binding activity in a gel shift assay. The arrows indicate specific bands for the AP-1 binding complexes induced in the dorsal parietal cortex by acute $\operatorname{ECS}(A)$ and chronic ECS $(B)$ treatment. The specific AP-1 bands decreased in intensity upon addition of increasing amounts $(0,3,10,30$, and $100 \mathrm{ng})$ of unlabeled wild-type HMT AP-1 oligonucleotide but not for the single base pair mutant AP-1(mut) oligonucleotide. The sequences of the oligonucleotides used for competition studies are shown at the bottom. The core consensus sequence for the AP-1 site is in boldface, while the single base altered in the mutant oligonucleotide is underlined.

optical density of specific bands using an image analysis system with the NIH IMAGE software, version 1.41 , or by counting cpm in specific bands using a $\beta$ etascope blot analyzer (Betagen).

The AP-1 probe was a double-stranded synthetic oligonucleotide (19. mer) identical to that employed by Sonnenberg et al. (1989), derived from the promoter sequence of the human metallothionein (HMT) gene. The probe was labeled with $\alpha-{ }^{32} \mathrm{P}-\mathrm{dGTP}$ and $\alpha-{ }^{32} \mathrm{P}-\mathrm{dTTP}$ to a specific activity of $4-9 \times 10^{8} \mathrm{cpm} / \mu \mathrm{g}$ by the Klenow fill-in reaction.

For competition assays, $0,3,10,30$, and $100 \mathrm{ng}$ amounts of competitor DNA were added to the gel shift reaction 20 min before addition of the labeled probe. The sequences of the wild-type HMT AP-1 oligonucleotide and its mutant are shown in Figure 1. The other oligonucleotides used for competition studies are shown in Figure 9.

Supershift experiments were performed by incubating $0.2 \mu \mathrm{l}$ of an Fra antibody (kindly provided by Dr. Michael Iadarola, NIDR, NIH, Bethesda) with the gel shift reaction components for $1 \mathrm{hr}$ at $4^{\circ} \mathrm{C}$ before addition of the labeled probe.

In some experiments, c-Fos and c-Jun proteins derived from rabbit reticulocyte lysates (kindly provided by Drs. Steven Hyman and Christine Konradi, Harvard Medical School) were studied in gel shift assays, as described above, for comparison.

Western blotting. Nuclear extracts for Western blots were obtained by a modification of the method of Sonnenberg et al. (1989). The tissue was homogenized in Dounce homogenizers in $10 \mathrm{vol}$ of $0.25 \mathrm{M}$ sucrose, 15 mм Tris- $\mathrm{HCl}, \mathrm{pH} 7.9,60 \mathrm{~mm} \mathrm{KCl,} 15$ mм NaCl, 5 mм EDTA, 1 mM EGTA, $0.15 \mathrm{~mm}$ spermine, $0.5 \mathrm{~mm}$ spermidine, $5 \mathrm{~mm}$ DTT, and the protease inhibitors, $2 \mu \mathrm{g} / \mathrm{ml}$ leupeptin, $5 \mu \mathrm{g} / \mathrm{ml}$ aprotinin, $0.2 \mathrm{~mm}$ PMSF, and homogenates were centrifuged at $2,000 \times \mathrm{g}$ for $10 \mathrm{~min}$ at $4^{\circ} \mathrm{C}$. The pellets were resuspended in the original volume of $10 \mathrm{~mm}$ HEPES, pH 7.9, $1.5 \mathrm{~mm} \mathrm{MgCl}_{2}, 10 \mathrm{~mm} \mathrm{NaCl}, 5 \mathrm{~mm}$ DTT, and the protease inhibitors and centrifuged at $4000 \times g$ for $10 \mathrm{~min}$ at $4^{\circ} \mathrm{C}$. The pellets were resuspended in $50 \mathrm{~mm}$ HEPES, pH 7.9, $0.75 \mathrm{~mm} \mathrm{MgCl}_{2}$, 

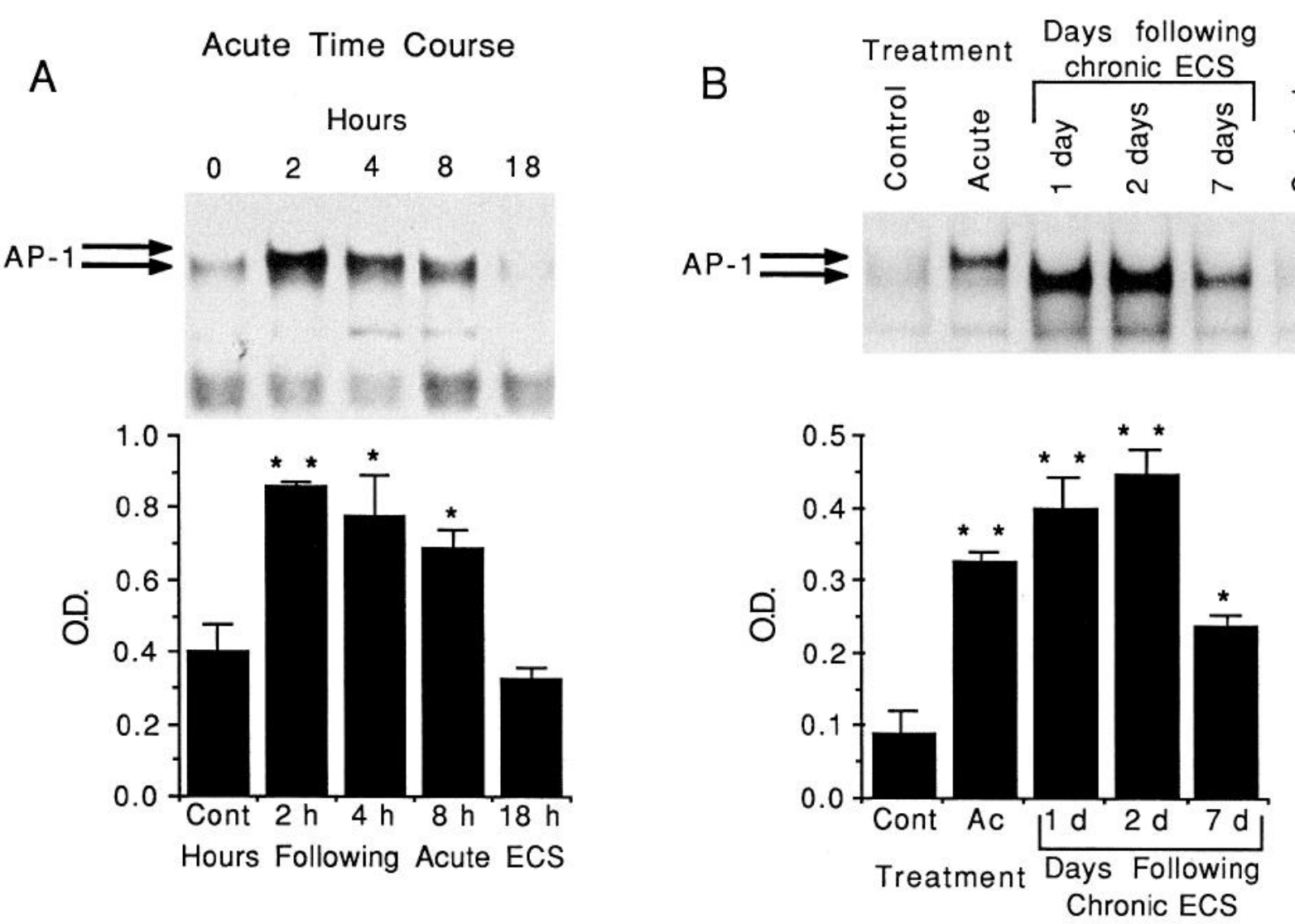

Figure 2. Representative autoradiograms of a gel shift assay showing the time course for AP-1 binding in the dorsal parietal cortex following a single acute ECS $(A)$ and chronic ECS treatment $(B)$. The two specific AP-1 bands are indicated by arrows. Note that the more intense upper band induced by acute ECS migrates more slowly than the AP-1 band induced by chronic ECS treatment. The bar graphs indicate the optical densities obtained from autoradiograms of gel shift assays of AP-1 binding for these time courses. Control indicates the sham-treated control rats and acute (in $B$ ) indicates the rats killed $2 \mathrm{hr}$ following acute ECS. Data are expressed as mean \pm SEM and represent $n=3$ for each time point [ ${ }^{*}, p<0.05$; **, $p<0.01$; relative to the control $(0 \mathrm{hr})$ time point, Student's $t$ test].

$0.5 \mathrm{~mm}$ EDTA, $0.5 \mathrm{M} \mathrm{NaCl}, 12.5 \%$ glycerol, 5 mм DTT, and the protease inhibitors, and incubated on a rotating shaker for $60 \mathrm{~min}$ at $4^{\circ} \mathrm{C}$ and then centrifuged at $15,000 \times \mathrm{g}$ for $30 \mathrm{~min}$ at $4^{\circ} \mathrm{C}$. The final nuclear extracts were dialyzed overnight at $4^{\circ} \mathrm{C}$ into $5 \mathrm{~mm}$ Tris- $\mathrm{HCl}, \mathrm{pH} 7.9$, $0.1 \mathrm{~mm}$ PMSF and then lyophilized. The pellets were resuspended by sonication in $250 \mu \mathrm{l}$ of $2 \%$ SDS. Fifty micrograms of protein of these nuclear extracts were then applied to a $10 \%$ acrylamide $/ 0.27 \% N, N^{\prime}$ methylenebisacrylamide resolving gel for SDS polyacrylamide gel electrophoresis overnight at $60 \mathrm{~V}$ and electrotransferred to nitrocellulose at $50 \mathrm{~V}$ for $4 \mathrm{hr}$. The blots were blocked with $4 \times 15$ min changes of $2 \%$ nonfat dry milk powder in PBST (10 mm sodium phosphate, $\mathrm{pH} 7.4$, $150 \mathrm{~mm} \mathrm{NaCl}, 0.1 \%$ Tween-20) and incubated overnight on a shaker at $4^{\circ} \mathrm{C}$ in a 1:4000 dilution of Fra antibody (see above) in blocking buffer with $0.05 \%$ sodium azide. The blots were washed $4 \times 15 \mathrm{~min}$ in blocking buffer and incubated in a 1:2000 dilution of goat anti-rabbit antibody conjugated to horseradish peroxidase (Vector Labs) in blocking buffer for $2 \mathrm{hr}$. The blots were washed $8 \times 15 \mathrm{~min}$ with PBST alone and developed with the enhanced chemiluminescence (ECL) system of Amersham, and exposed to Hyperfilm-ECL (Amersham) for 5-60 sec. The levels of Fra immunoreactivity were quantified by measuring the optical density of specific bands using an image analysis system with the NIH IMAGE software, version 1.41 .

\section{Results}

Acute ECS regulation of $A P-1$ binding

In our gel shift assays, we used a double-stranded oligonucleotide probe containing a consensus AP-1 site that had been characterized previously by Sonnenberg et al. (1989). Gel shift assays using this AP-1 probe result in a strong upper doublet and two minor, variably present lower bands (Fig. $1 \mathrm{~A}$ ). Addition of unlabeled HMT AP-1 oligonucleotide to the gel shift assay potently decreased the intensity of the upper doublet. In contrast, competition with a mutant HMT AP-1 oligonucleotide did not decrease the intensity of the doublet. The mutant oligonucleotide contains a single base pair mutation in the AP-1 consensus sequence previously shown to abolish DNA binding and transcriptional activation by the AP-1 complex (Angel et al., 1987). These competition studies reveal that the upper doublet represents the major AP-1 binding activity in acute ECS brain extracts.

The time course for induction of AP-1 binding in the dorsal parietal cortex in response to an acute ECS is shown in Figure $2 A$. AP-1 binding was highest $2-4 \mathrm{hr}$ after the ECS and had returned to control levels within $18 \mathrm{hr}$. Following acute ECS, the top band of the doublet was much more prominent than the lower band. The frontal cortex and hippocampus had similar acute time courses, although levels of AP-1 binding in the hippocampus remained slightly higher than control levels $18 \mathrm{hr}$ following an acute ECS. These time courses are similar to those shown by Sonnenberg et al. (1989) for the hippocampus.

\section{Chronic ECS regulation of $A P-1$ binding}

Acute ECS produced a similar induction of AP-1 binding in the dorsal parietal cortex of animals that were sham treated chron- 
FRONTAL CORTEX

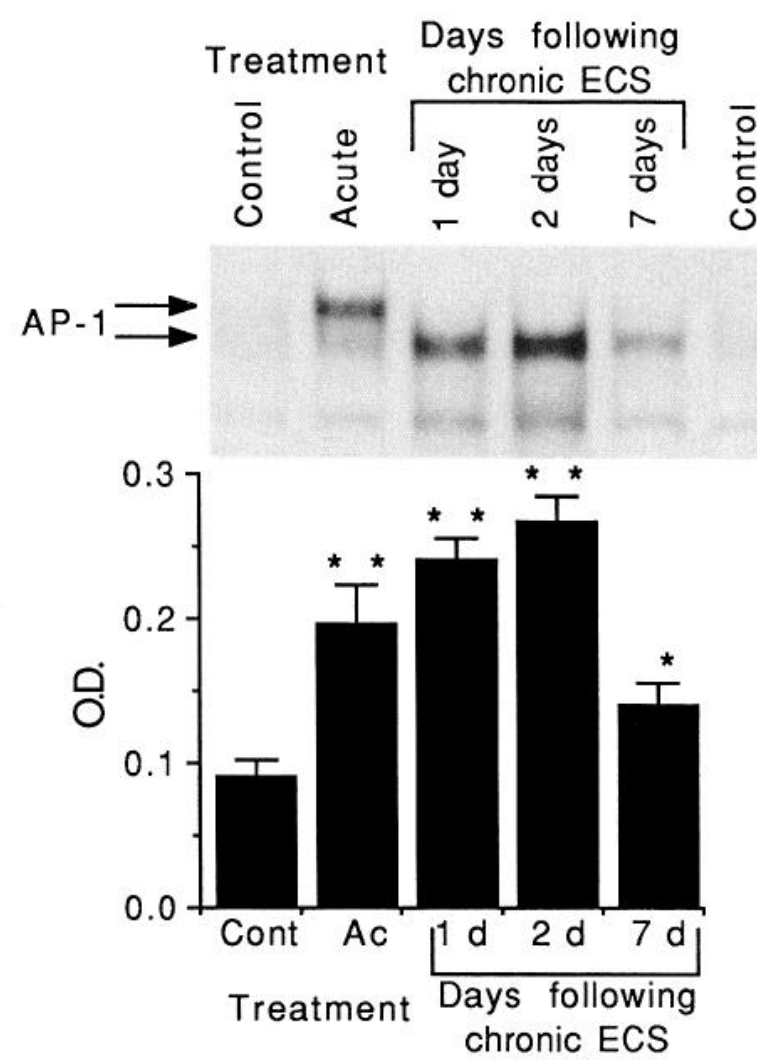

HIPPOCAMPUS
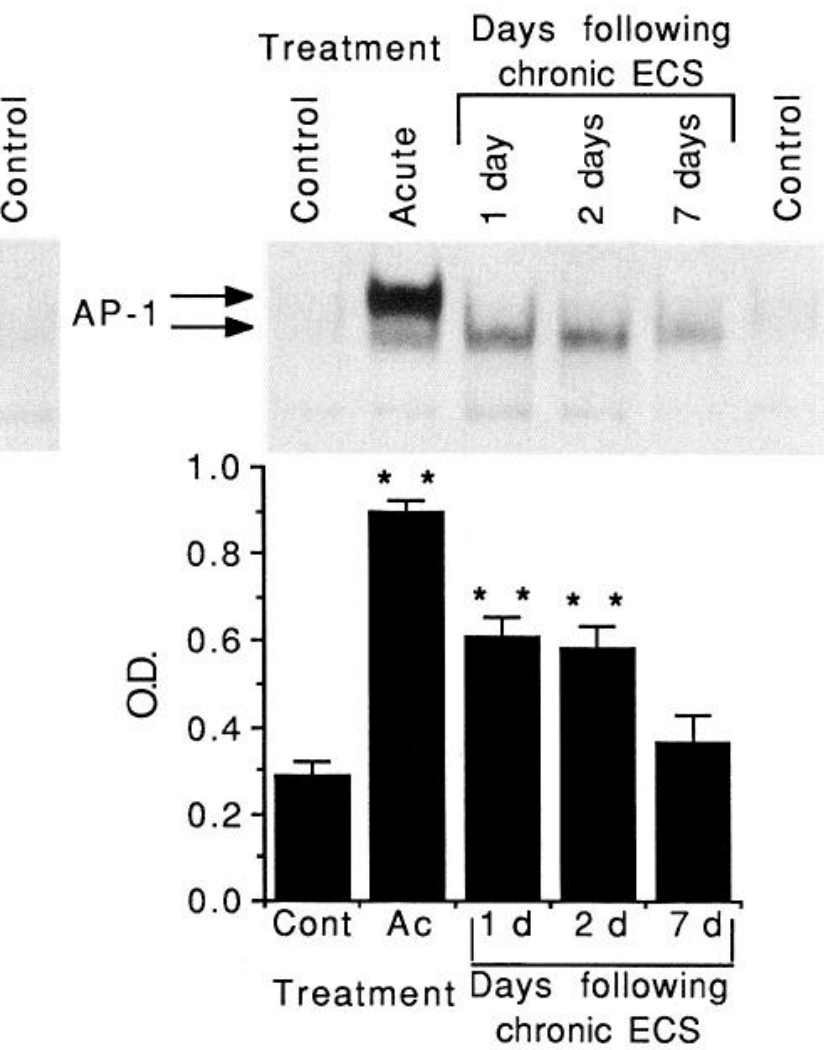

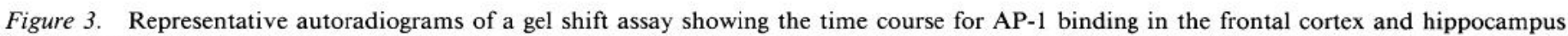

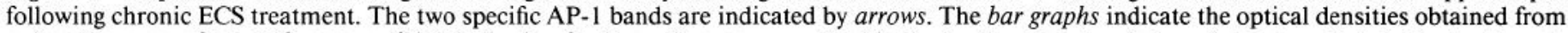

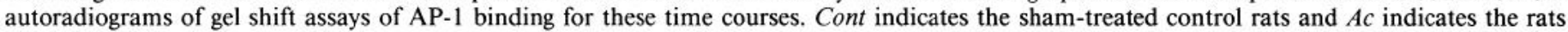

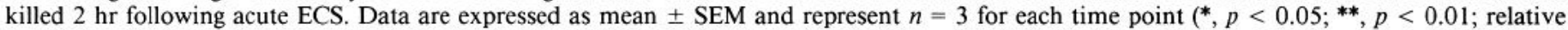
to the control time point, Student's $t$ test).

ically for $10 \mathrm{~d}$ before receiving an acute ECS on day 11 (Fig. $2 B$ ). In contrast, $18 \mathrm{hr}$ after the last of 10 daily ECS treatments, AP-1 binding in the dorsal parietal cortex was still significantly elevated, even above acute levels (Fig. $2 B$ ). AP-1 binding levels continued to be significantly elevated 2 and $7 \mathrm{~d}$ following the last chronic ECS treatment. Binding levels $2 \mathrm{~d}$ following chronic ECS treatment appeared to be even higher than the $1 \mathrm{~d}$ time point. This is in marked contrast to the time course shown for a single acute ECS (Fig. $2 A$ ), where AP-1 binding had returned to control levels $18 \mathrm{hr}$ after the ECS.

The specific AP-1 band induced following chronic ECS treatment is formed predominantly by the lower, faster migrating band of the doublet. Little, if any, of the top band is present (Fig. 2B). As with the acute AP-1 bands, the intensity of the chronic AP-1 band was decreased with the addition of unlabeled HMT AP-1, but not by the mutant HMT AP-1, oligonucleotide (Fig. $1 B$ ). Fos/Jun heterodimers produced from reticulocyte lysates resulted in an AP-1 band that migrated at a rate approximating that of the acute AP-1 band, and clearly distanced from that of the chronic AP-1 band (data not shown). The difference in migration rates for acutely and chronically induced AP-1 bands raised the possibility that the composition of the two complexes is different.

Similar increases in AP-1 binding levels were observed in the frontal cortex and hippocampus $1 \mathrm{~d}$ following the last chronic ECS treatment (Fig. 3). These two regions also displayed similar migration rates for the acute and chronic AP-1 bands in the gel shift assay, with the upper band induced acutely and the lower band induced chronically. AP-1 binding levels in the frontal cortex, but not the hippocampus, were still significantly higher 2 and $7 \mathrm{~d}$ following chronic ECS, similar to that found for the parietal cortex.

An acute ECS challenge $18 \mathrm{hr}$ following chronic ECS treatment did not significantly increase AP-1 binding levels in the dorsal parietal cortex (Fig. 4). However, an acute ECS challenge did significantly increase AP-1 binding levels in the frontal cortex and hippocampus. Overall, the acute ECS-induced increase of further AP-1 binding following chronic ECS treatment was far less than that following chronic sham treatment (data not shown). These results suggest that desensitization of acute induction of AP-1 binding following chronic treatment may occur in all three regions examined, but that desensitization is more effective in the dorsal parietal cortex than in the frontal cortex and hippocampus.

\section{Supershifts of the AP-1 binding complexes}

Supershift experiments were performed to study the composition of the AP-1 complex in both the acute and chronic ECStreated animals. Affinity-purified polyclonal antibodies made against the M-peptide of c-Fos, which also detects numerous Fras, were added to the gel shift assay (see Materials and Methods). These antibodies completely abolished the specific AP-1 bands from control, acute, chronic, and chronic + acute animals (Fig. 5). The majority of AP-1 binding appeared to be disrupted, 

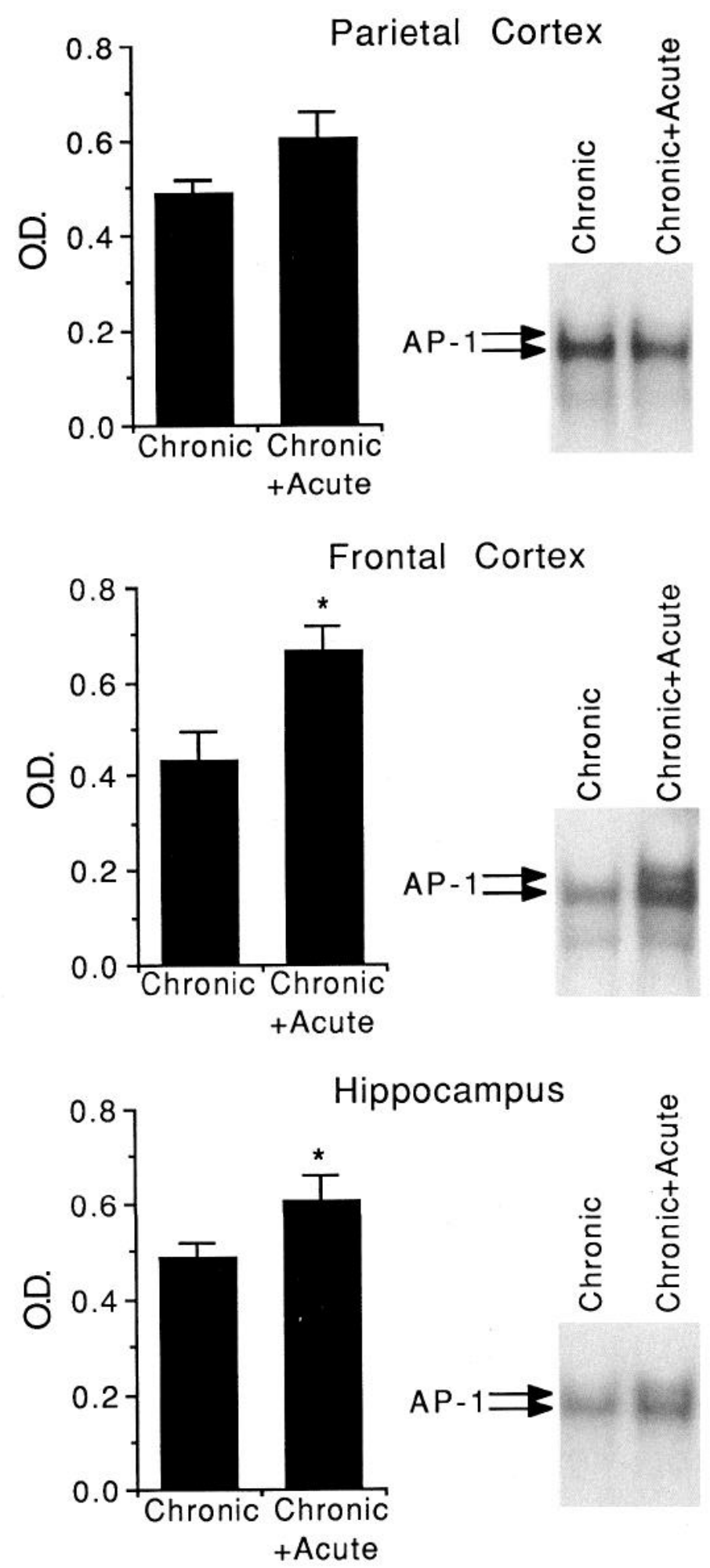

Figure 4. Representative autoradiograms of gel shift assays showing AP-1 binding in parietal and frontal cortex and hippocampus following chronic plus acute ECS treatment. Rats received daily ECS for $10 \mathrm{~d}$. On day 11, rats were given either an acute sham treatment (chronic) or an acute ECS (chronic +acute). The two specific AP-1 bands are indicated by arrows. The bar graphs indicate the optical densities of both AP-1 bands together obtained from autoradiograms of gel shift assays of AP-1 binding. Data are expressed as mean \pm SEM and represent $n$ $=3$ for each time point $\left({ }^{*}, p<0.05\right.$ relative to the chronic treatment, Student's $t$ test). rather than simply supershifted, by the antibodies. This is not surprising because the antibodies were made against a portion of the Fos-related proteins that is important for DNA binding. The small amount of more slowly migrating "supershifted" bands apparent in the figure is probably due to a minor population of the polyclonal antibodies binding to epitopes of the Fos-related proteins that are not critical for DNA binding. These findings suggest that the AP-1 binding activity present under all four treatment conditions contained c-Fos and/or Fras as a component of the AP-1 complex. As a positive control, the Fra antibody supershifted heterodimers of c-Fos and c-Jun from reticulocyte lysates bound to the labeled HMT AP-1 probe (Fig. 5). As a negative control, the Fra antibody did not supershift a DNA-binding complex bound to a labeled somatostatin CRE (cAMP-regulated element) probe, which is composed of distinct proteins (data not shown). In addition, the AP-1 probe alone or the probe with the Fra antibody, in the absence of tissue, did not produce a supershifted band or any other significant labeling (data not shown).

\section{Western blots of Fra immunoreactivity}

Given that the AP-1 complexes observed under acute and chronic ECS conditions appeared to contain Fra-like proteins, we prepared Western blots of parietal cortex nuclear extracts to study the identity of the Fras involved. Similar to previous studies in the hippocampus (Sonnenberg et al., 1989), a single acute ECS increased several Fras in the cortex that peaked at different time points (Fig. 6A). A $58 \mathrm{kDa}$ band, probably corresponding to c-Fos, peaked at $2 \mathrm{hr}$ and rapidly decreased by $4 \mathrm{hr}$. Several Fra bands between 35 and $45 \mathrm{kDa}$ peaked at about $6 \mathrm{hr}$. All Fras were at or near control levels by the 8 and $18 \mathrm{hr}$ time points. In contrast, there appeared to be an intense, broad doublet of $35-37 \mathrm{kDa} 18 \mathrm{hr}$ following the last chronic ECS. Western blots performed at different times resolved this doublet to slightly differing degrees. However, on most blots there were two intensely labeled bands of approximately 35 and $37 \mathrm{kDa}$ in chronic samples, which did not appear at any of the acute time points. This is best shown in Figure $6 B$, where the chronically induced Fra doublet is well resolved and does not correspond to any of the bands in the acute ( $2 \mathrm{hr}$ ECS) sample. The upper $37 \mathrm{kDa}$ band is much more prominent than the lower $35 \mathrm{kDa}$ band of the doublet. These differences in migration rates between acute and chronic ECS bands can also be seen in Figure $6 D$. The induction of different proteins is consistent with the different migration rates of the chronic versus the acute AP-1 complex in gel shift assays. Analysis of frontal cortex and hippocampus revealed similar findings for the acute and chronic ECS conditions, with chronic ECS associated with the induction of the 35-37 kDa doublet. Additional Fras were also apparent at low levels in some Western blots of chronic ECS samples from cortex or hippocampus (data not shown).

Preabsorption of the Fra antibody with M-peptide (Bachem, CA) abolished all bands between 30 and $60 \mathrm{kDa}$ in both the acute and chronic ECS samples (Fig. $6 \mathrm{C}$ ). The intensities of several nonspecific bands of approximately $84 \mathrm{kDa}$ were not decreased with addition of the M-peptide. This demonstrated the specificity of these Fra bands. Nuclear extracts had far more intense Fra bands, relative to whole-cell extracts, for both acute and chronic samples (Fig. 6D). Therefore, the chronically induced Fras appear enriched in the nucleus, similar to the acutely induced Fras.

After a course of chronic ECS treatment, an acute ECS in- 


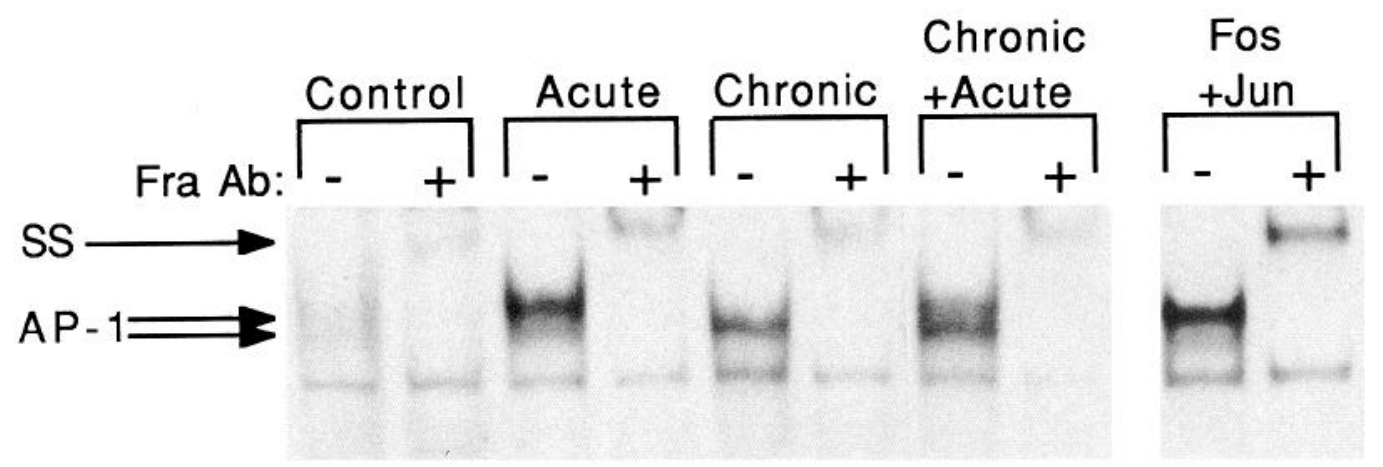

Figure 5. Supershifts of AP-1 binding complexes from the parietal cortex of ECS-treated animals. No antibody $(-)$ or $0.2 \mu \mathrm{l}$ of Fra antibody (+) was added to gel shift assays of AP-1 binding in control, acute $(2 \mathrm{hr})$ ECS, chronic ECS, and chronic + acute ( $2 \mathrm{hr})$ ECS samples, $1 \mathrm{hr}$ before addition of the radioactively labeled AP-1 probe (see Materials and Methods). The two Fos +Jun lanes show a supershift of the c-Fos/c-Jun heterodimer produced from reticulocyte lysates. In all cases, the addition of the Fra antibody abolished both specific AP-1 bands and produced a less intense, slower-migrating supershifted $(S S)$ complex.

duced certain Fras in the parietal cortex in some animals, such as the ones shown in Figure $6 \mathrm{~A}$. However, this was not a consistent finding. In most animals, an acute ECS did not significantly induce Fra-like immunoreactivity, consistent with a decrease in the induction of AP-1 binding under these conditions (see Fig. 4).

Similar to the time course observed for AP-1 binding in the dorsal parietal cortex (Fig. $2 B$ ), the prominent upper ( $37 \mathrm{kDa})$ band of the chronically induced Fra doublet (distinctly resolved in Fig. 7) remains maximally elevated $2 \mathrm{~d}$ following the last chronic ECS and decreases to about $60 \%$ after $7 \mathrm{~d}$. The lower, less intense $(35 \mathrm{kDa})$ band of the chronic Fra doublet also persists for $2 \mathrm{~d}$, but becomes nondetectable (as in control samples) at $7 \mathrm{~d}$.

\section{Development of chronic AP-1 binding and chronic Fras}

To study the time course of the effects of chronic ECS on AP-1 binding and Fras, animals received daily ECS treatments for 0 , 2,4 , or $8 \mathrm{~d}$, and were killed $18 \mathrm{hr}$ after the last ECS. The chronically induced Fras (the $35-37 \mathrm{kDa}$ doublet was not resolved in this experiment) were significantly elevated following $2 \mathrm{~d}$ of ECS treatments, and appeared to reach maximal levels after $4 \mathrm{~d}$ (Fig. 8). A similar time course was observed for AP-1 binding (data not shown). The similar time courses further suggest that the chronically induced Fra doublet forms a necessary component of the chronically induced AP-1 binding complex.

\section{Relative binding affinities for the acute and chronic AP-1 complexes}

Evidence that the acute and chronic AP-1 complexes may possess different functional properties was obtained from competition studies (Fig. 9). The $\mathrm{IC}_{50}$ (the concentration of competing oligonucleotide required for half-maximal inhibition of AP-1 binding) of the Fos CARE oligonucleotide (a CRE and AP-1like site in the c-fos gene) was close to twofold lower for the acute AP-1 complex relative to that for the chronic AP-1 complex $[32.6 \pm 6.2$ vs $56.5 \pm 1.4 \mathrm{ng} / 30 \mu \mathrm{l}$ (mean \pm SEM), respectively]. This difference in $\mathrm{IC}_{50}$ is statistically significant ( $p$ $<0.05$, Student's $t$ test), and suggests a greater affinity of the acute AP-1 binding complex for the Fos CARE site. In contrast, competition studies revealed nearly identical relative affinities of acute and chronic AP-1 complexes for the HMT AP-1, tyrosine hydroxylase AP-1 (TH AP-1), the prodynorphin non- canonical AP-1 site (dynorphin AP-1) (Naranjo et al., 1991), and somatostatin CRE (SS CRE) oligonucleotides. Overall, the prodynorphin AP-1 and Fos CARE sites had far less affinity for both AP-1 complexes than the TH AP-1 and SS CRE sites. Additionally, the c-fos AP-1 like sequence (FAP) had a relative affinity for both AP-1 complexes similar to that observed for the prodynorphin AP-1 site (data not shown). Neither complex showed any affinity for the AP-2 and C/EBP consensus sites, the proenkephalin AP-4 site, or the c-fos dyad symmetry element (data not shown), further demonstrating the specificity of the AP-1 bands studied.

\section{Discussion}

The major finding of this study is that chronic ECS, while desensitizing the ability of a subsequent ECS to induce certain IEGs (e.g., c-fos and c-jun), results in a persistent increase in AP-1 binding activity in rat cerebral cortex and hippocampus. Evidence was obtained to suggest that this persisting chronic AP-1 complex is composed, at least in part, of different Fras compared to the AP-1 complex induced by a single acute ECS. This switch from the acute AP- 1 complex to the chronic AP-1 complex could contribute to regulation of certain proteins by repeated ECS at the level of gene expression (e.g., Leviel et al., 1990; Nestler et al., 1990; Kapur et al., 1993).

Similar to the study of Sonnenberg et al. (1989) in hippocampus, peak levels of AP-1 binding were induced in the frontal and parietal cortex and in the hippocampus approximately $2 \mathrm{hr}$ following an acute ECS. Levels of AP-1 binding then returned to control levels within $18 \mathrm{hr}$. In contrast, levels of AP-1 binding were as high, and in most animals higher, in the cortex $18 \mathrm{hr}$ after the last chronic ECS treatment and persisted for at least 7 d. This phenomenon is similar to a previous study where chronic cocaine treatment induced a similarly long-lasting AP-1 binding complex in the nucleus accumbens (Hope et al., 1992) and striatum (Hope et al., 1993).

Supershift studies indicate that the AP-1 binding complex induced by chronic ECS contains one or more Fras. Western blots demonstrate that chronic ECS results in the expression of a novel Fra doublet of 35 and $37 \mathrm{kDa}$ that is not detected after a single acute ECS. The time courses for the induction of the chronic AP-1 complex and of the $37 \mathrm{kDa}$ Fra band by repeated ECS were similar, as was the rate at which the AP-1 binding and Fra bands returned to control levels following the last chron- 


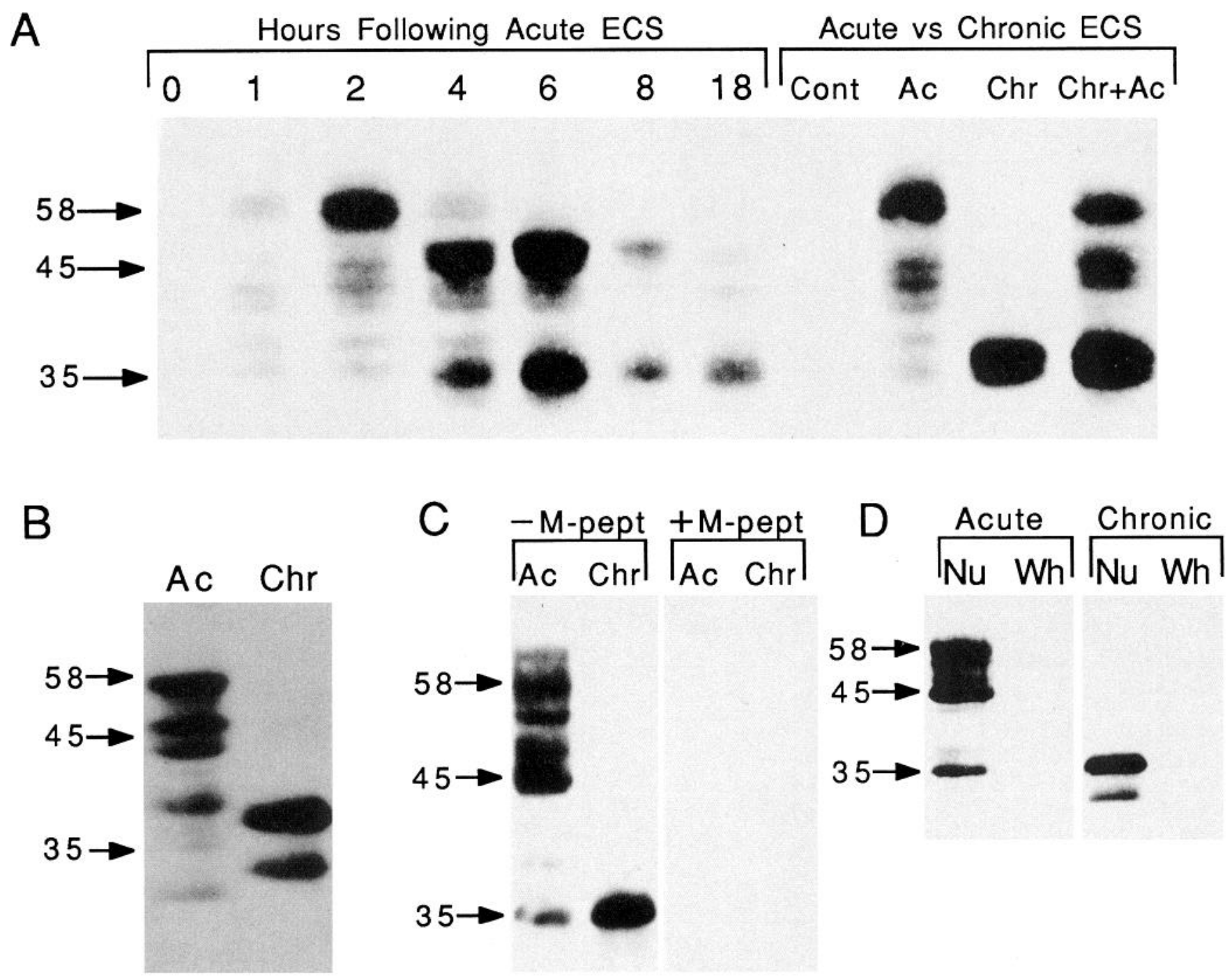

Figure 6. Fra immunoblots of parietal cortex for acute and chronic ECS treatments. $A$, Time course for Fra immunoreactivity following a single acute ECS $(0-18 \mathrm{hr})$. Three groups of Fra bands of approximately 58,45 , and $35 \mathrm{kDa}$ appear at different time points. The last four lanes in $A$ show Fra immunoreactivity following acute and chronic treatments: control $(C o n t)$, acute $(2 \mathrm{hr})(A c)$, chronic $(C h r)$, chronic + acute $(2 \mathrm{hr})(C h r+A c)($ see Materials and Methods). There is an intense doublet of $35-37 \mathrm{kDa}$ in the chronic ECS-treated samples. $B$, A well-resolved Fra immunoblot of the acute $(2 \mathrm{hr})(A c)$ and chronic $(C h r)$ samples. The two lower bands in the acute sample, which show the same $M_{r}$ at 2,4 , and $6 \mathrm{hr}$, do not migrate at the same rate as the 35 and $37 \mathrm{kDa}$ bands of the doublet in the chronic sample. $C$, Preabsorption of the Fra antibody with the M-peptide antigen $(+M$-pept $)$ abolishes the acute $(A c)$ and chronic $(C h r)$ ECS-induced Fra bands. An immunoblot performed at the same time without preabsorption of the antibody is also shown $(-M$-pept $)$. $D$, Fra immunoblots of nuclear extracts $(N u)$ and whole-cell extracts $(W h)$ from acute and chronic samples. The whole-cell extracts were supernatants collected after centrifugation of tissue homogenized in EMSA buffer (see Materials and Methods). The nuclear extracts were prepared as described in Materials and Methods. Nuclear extracts display intense Fra bands while those from whole-cell extracts are barely detectable.

ic ECS. The less prominent $35 \mathrm{kDa}$ band had a similar time course but was not detectable at low levels. This provides correlative evidence that the $35-37 \mathrm{kDa}$ Fra doublet represents major components of the chronic AP-1 binding complex. The other major component of the chronic AP-1 complex is probably a Jun-like protein, based on the fact that all known Fos-like proteins must heterodimerize with a Jun-like protein to form high-affinity AP-1 binding complexes (Morgan and Curran, 1991). Unfortunately, we were unable to study this possibility directly. Several anti-Jun antibodies tested failed to work in supershift assays (e.g., the antibodies failed to disrupt an acute ECS AP-1 complex or Fos/Jun heterodimers from reticulocyte lysates) and in Western blot experiments (e.g., the antibodies failed to detect Jun-like proteins in an acute ECS sample) (unpublished observations).

Several lines of evidence suggest that the AP-1 binding complex and 35-37 kDa Fra doublet induced by chronic ECS treatment were different from those induced by an acute ECS. (1) The chronic AP-1 complex migrated faster, and as a distinct band, in the gel shift assay compared to the acute AP-1 complex. (2) The chronically induced $35-37 \mathrm{kDa}$ Fra doublet did not appear to be induced by acute ECS treatment. However, there may be some partial overlap of acutely induced Fra bands with the other Fra bands observed following chronic ECS treatment. In such cases, these minor chronic Fra bands may represent a residual of the last ECS treatment, which accumulates with re- 

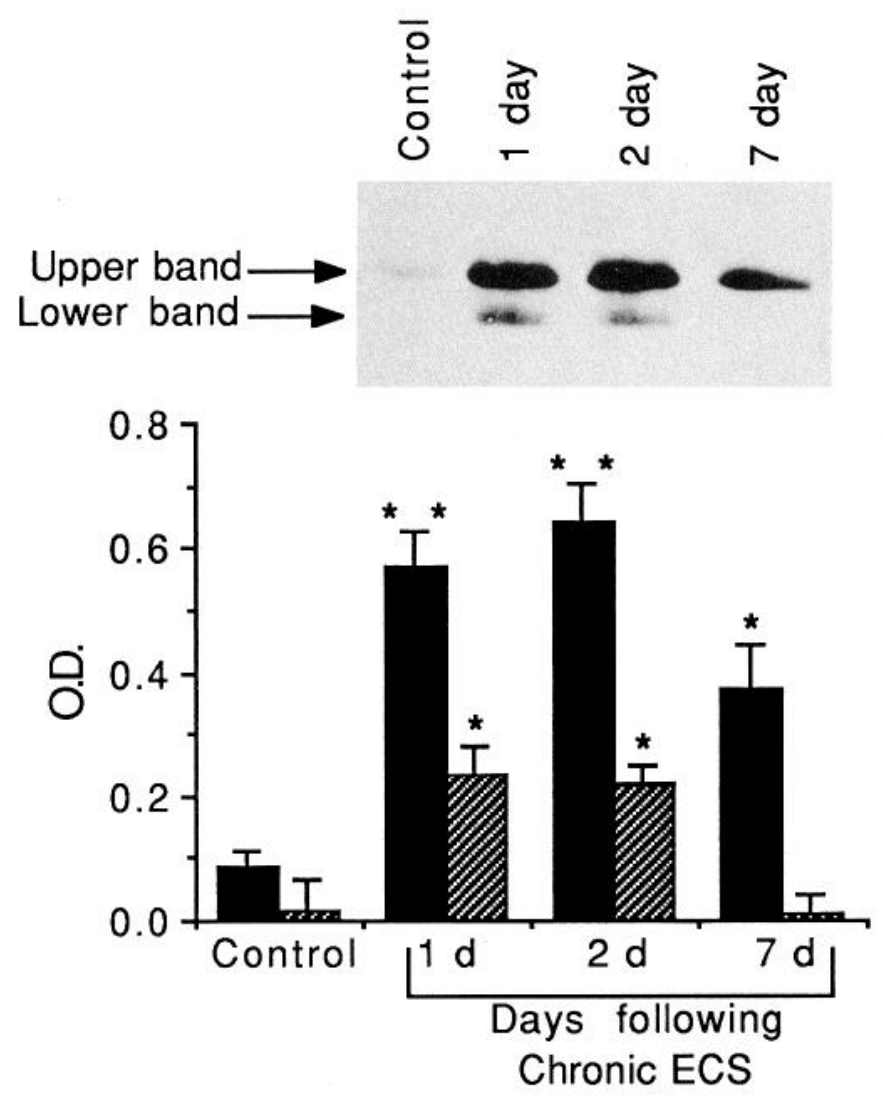

Figure 7. Representative immunoblot showing persistence of the 35$37 \mathrm{kDa}$ Fra-immunoreactive bands 1, 2, and $7 \mathrm{~d}$ following chronic ECS treatment. The chronically induced Fra doublet is resolved as an upper $(37 \mathrm{kDa})$ and lower $(35 \mathrm{kDa})$ band. The bar graphs indicate the optical densities for the upper (solid bars) and lower (hatched bars) bands obtained from the above immunoblots. Data are expressed as mean \pm SEM and represent $n=3$ for each time point $\left({ }^{*}, p<0.05 ;{ }^{* *}, p<0.01\right.$; relative to the control samples, Student's $t$ test).

peated treatments. (3) Both the chronic AP-1 binding complex and at least the $37 \mathrm{kDa}$ Fra band remained elevated at $60 \%$ of maximal levels $7 \mathrm{~d}$ following the last chronic ECS treatment. In contrast, the acutely induced AP- 1 binding complex and Fras returned to control levels within $18 \mathrm{hr}$. The chronically induced AP-1 binding complex and 35-37 kDa Fra doublet would therefore appear to be unique to chronic ECS treatment.

More recent studies indicate that a long-lasting AP-1 complex and the chronically induced Fras are also associated with other chronic treatments. Cocaine, which produces transient increases in AP-1 binding and levels of c-Fos and certain Fras in striatum after acute administration (Graybiel et al., 1990; Young et al., 1991; Brown et al., 1992; Hope et al., 1992), induces a persistent increase in both AP-1 binding activity and a $37 \mathrm{kDa}$ Fra band after chronic administration (Hope et al., 1992, 1993). Tranylcypromine, a monoamine oxidase inhibitor antidepressant that increases AP-1 binding activity and c-Fos expression in frontal cortex acutely, also increases AP-1 binding activity and a prominent Fra doublet of approximately $35-37 \mathrm{kDa}$ after chronic treatment (unpublished observations). As with chronic ECS, the long-lasting chronic cocaine- and tranylcypromine-induced AP-1 binding complex migrates with the lower band of the specific AP-1 doublet, further establishing an association between the persistent, chronic AP-1 binding activity and the $35-37 \mathrm{kDa}$ Fra doublet. Finally, apomorphine, which acutely induces c-Fos

\section{Days of Chronic ECS Treatment}
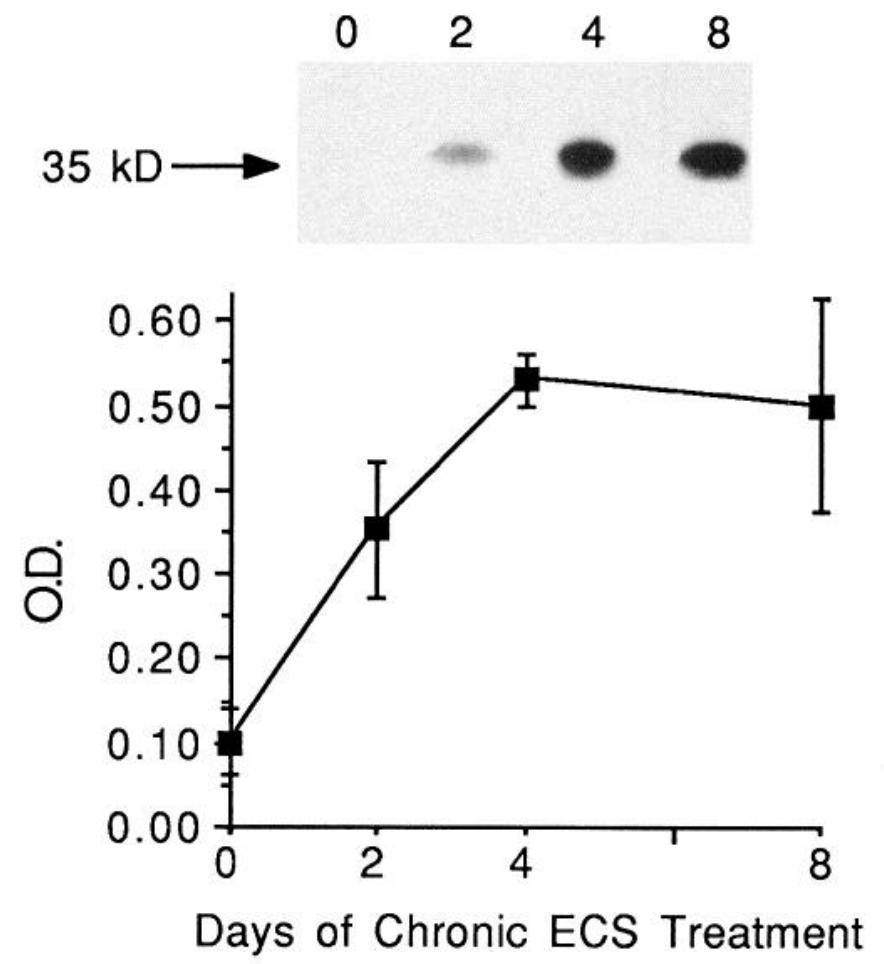

Figure 8. Representative immunoblot showing the gradual induction of the 35-37 kDa Fra-immunoreactive bands following 0, 2, 4, and 8 $\mathrm{d}$ of repeated ECS treatment. In this figure, the lower $(35 \mathrm{kDa})$ band shown in Figure 7 is not completely resolved from the more intense upper $(37 \mathrm{kDa})$ band. The line graph indicates the optical densities of the bands obtained from the above immunoblots. Data are expressed as mean \pm SEM and represent $n=3$ for each time point.

and certain Fras in the striatum of animals that received 6-hydroxydopamine lesions of the substantia nigra, was reported to induce a prominent Fra band of approximately 35 $\mathrm{kDa}$ after repeated administration (Pennypacker et al., 1992). We have found that this $35 \mathrm{kDa}$ band corresponds to the 37 $\mathrm{kDa}$ Fra band induced by the other chronic treatments (B. T. Hope, D. W. Self, and E. J. Nestler, unpublished observations). Together, these findings raise the possibility that induction of the 35-37 kDa Fra doublet and the associated formation of a long-lasting AP-1 complex may represent a general response of the nervous system to repeated administration of stimuli that produce transient increases in c-Fos and AP-1 binding activity acutely. This induction could underlie some of the long-term adaptations seen in the brain in response to chronic, but not acute, perturbations. Based on the apparent unique association of the 35-37 kDa Fra doublet with chronic treatments, we have designated these proteins chronic Fras.

A major question, then, is the identity of the chronic Fras. One possibility is that they represent distinct gene products of Fos-like proteins that are induced in the brain in response to repeated stimuli. Another possibility is that the chronic Fras represent previously identified Fras that are induced by acute treatments but become modified (e.g., by phosphorylation) in response to repeated treatments. For example, phosphorylation and other posttranslational modifications are known to alter the migration of proteins in nondenaturing and denaturing gels. Phosphorylation has also been known to alter the degradation 


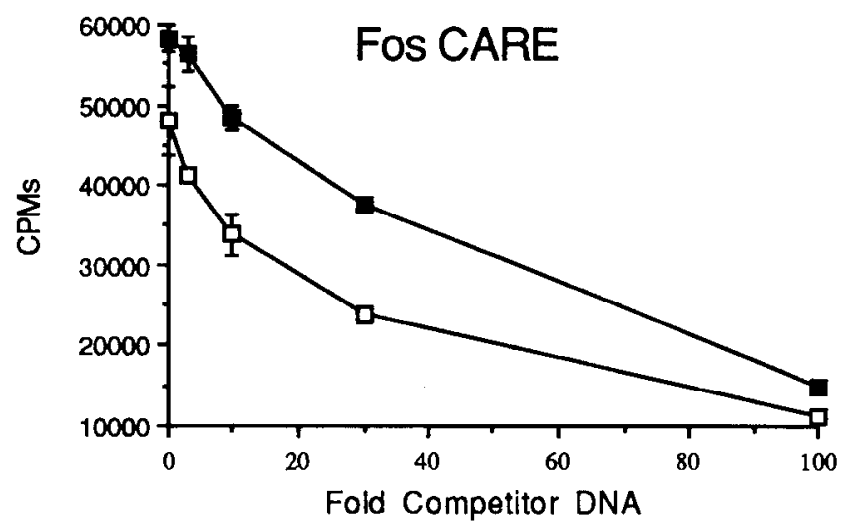

Oligonucleotides for Competition Assay

FOS CARE GATCCCGTGACGTTTACAC

HMT AP-1 TCGACGTGACTCAGCGCGC

TH AP-1 GATCAGGGTGATTCAGAG

DYN AP-1 GATCAAGTGACAAACAGCGCT

SS CRE GATCGGCTGACGTCAGAG
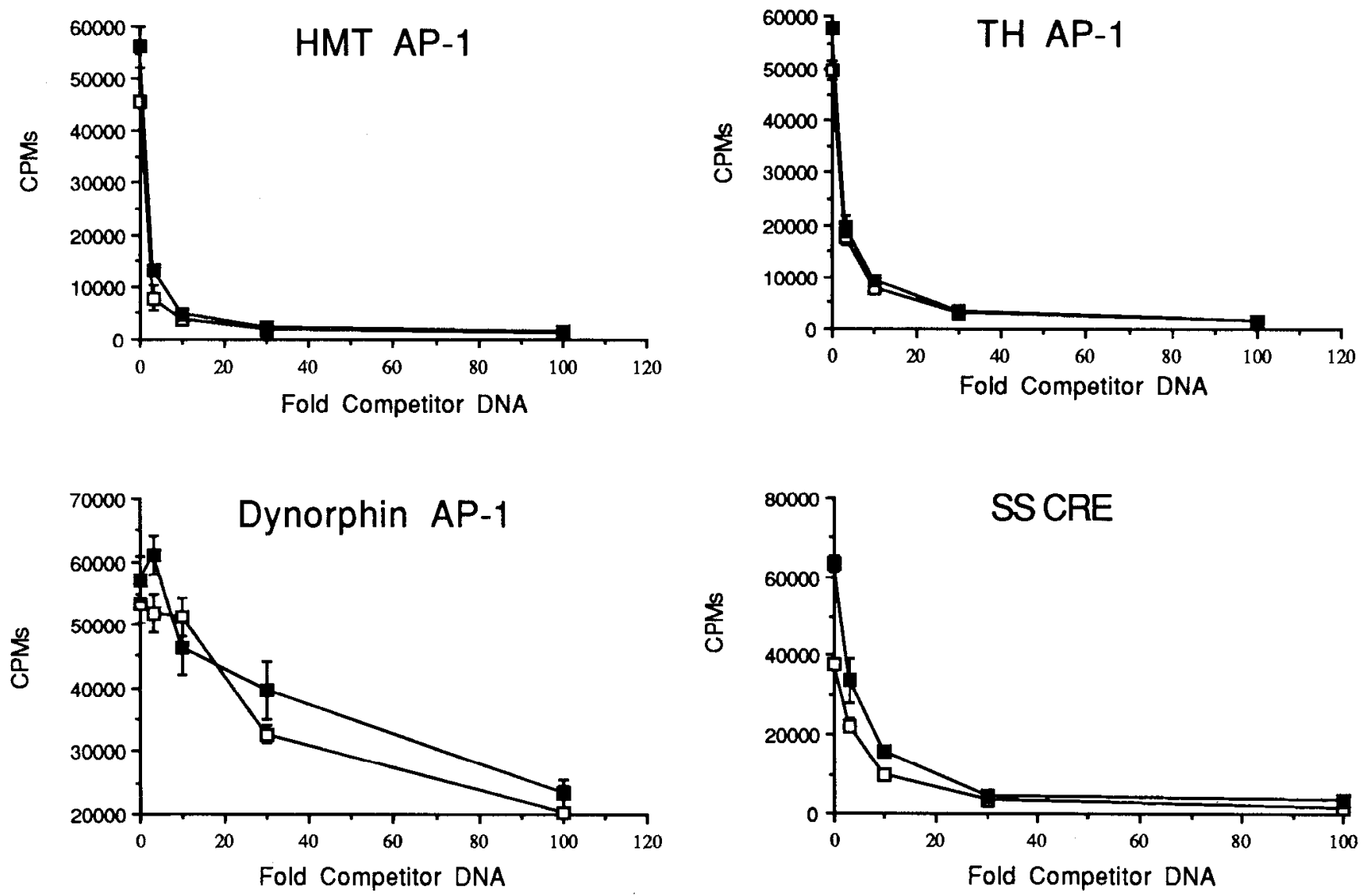

Figure 9. Line graphs of AP-1 binding in gel shift assays from oligonucleotide competition studies. Increasing amounts ( $0,3,10,30,100 \mathrm{ng})$ of the unlabeled oligonucleotides: c-fos calcium-regulated element (Fos CARE), human metallothionein AP-1 (HMT AP-I), tyrosine hydroxylase AP-1 (TH AP-1), dynorphin AP-1, or somatostatin cAMP-regulated element (SSCRE) were added to the gel shift assay 20 min before addition of $1 \mathrm{ng}$ of radioactively labeled HMT AP-1 probe. Fold Competitor DNA on the $\mathrm{x}$-axis indicates nanograms of competitor DNA per nanogram of radioactive probe DNA. Total $\mathrm{cpm}$ of radioactivity in the AP-1-specific bands was quantitated with a ßetascope (Betagen). The open squares indicate binding to the acute AP-1 complex; the solid squares indicate binding to the chronic AP-1 complex from parietal cortex. Data are expressed as mean \pm SEM and represent $n=3$ for each determination. The top right panel gives the DNA sequences of the oligonucleotides used in these competition studies, with the AP-1 or CRE core sequences in boldface.

rate of specific proteins (Papavassiliou et al., 1992; Lin and Desiderio, 1993). Therefore, it is conceivable that the longlasting AP-1 binding complex and the chronic Fras are due to posttranslational alterations of acutely induced Fras, which alter the migration and increase the half-lives of these proteins.

Whether the chronic Fras are due to phosphorylated forms of acutely induced Fras or represent novel proteins, the result is a long-lasting AP-1 binding complex that could have longlasting effects on genes that contain AP-1 sites in their pro- motcrs. This would allow regulation of the genes to continue via AP-1 sites long after the last chronic treatment. Considering the similar binding characteristics observed for the acute and chronic AP-1 complexes in competition studies, it is likely that many of the same AP-1 sites will be regulated. However, the twofold difference in the $\mathrm{IC}_{50}$ using the Fos CARE site suggests that the chronic AP-1 complex may bind to some AP-1-like sites with different relative affinities. Therefore, it is possible that the chronic AP-1 complex regulates a number of different 
genes than those regulated by the acute $\mathrm{AP}-1$ complex. Once bound to a given AP-1 site, it is possible that the transcriptional activating or repressing activity of the chronic AP-1 complex may be different from that of the acute AP-1 complex. Induction of chronic Fras and the chronic AP-1 complex may therefore result in a different pattern of gene expression with a longer duration of action.

The chronic AP- 1 complex appears maximally after $4 \mathrm{~d}$ of chronic ECS treatment. This is similar to the time course for the development of desensitization to the acute induction of c-fos and c-jun mRNA observed $18 \mathrm{hr}$ after the last chronic ECS treatment (Winston et al., 1990). The same desensitization phenomenon occurs in the nucleus accumbens and striatum following chronic cocaine treatment (Hope et al., 1992, 1993). Persico et al. (1993) had found a similar desensitization phenomenon in a number of different brain regions following chronic amphetamine administration. One possible function of the chronic Fras and the chronic AP-1 complex may be to mediate this desensitization: that is, to feedback on the c-fos, c-jun, and possibly other IEG promoters to inhibit further induction of the genes in response to acute stimuli.

Further work is clearly needed to identify the nature of chronic Fras and their functional activity as compared to c-Fos and other Fras. Nevertheless, the present study describes changes that occur in the brain in response to chronic administration of ECS and possibly other treatments as well. Some of these chronic ECS induced changes appear to be qualitatively different from those seen after acute ECS administration. These chronic changes could therefore mediate, or at the very least be representative of, the specific cellular and molecular adaptations responsible for long-term changes in brain function induced by ECS. Studies of the mechanisms by which ECS and the other treatments produce these changes will lead to a more complete understanding of the ways in which the brain responds to chronic perturbations.

\section{References}

Abate C, Marshak DE, Curran T (1991) Fos phosphorylated by p34cdc2, cAMP-dependent protein kinase and protein kinase $\mathrm{C}$ at multiple sites clustered within regulatory regions. Oncogene 6:2179-2185.

Angel P, Imagawa M, Chiu R, Stein B, Imbra RJ, Rahmsdorf HJ, Jonat $C$, Herrlich P, Karin M (1987) Phorbol ester-inducible genes contain a common cis element recognized by a TPA-modulated trans-acting factor. Cell 49:729-739.

Angcl P, Hattori K, Smcal T, Karin M (1988) The jun proto-oncogene is positively autoregulated by its product, Jun/AP-1. Cell 55:875885.

Bading H, Ginty DD, Greenberg ME (1993) Regulation of gene expression in hippocampal neurons by distinct calcium signaling pathways. Science 260:181-186.

Brown EE, Robertson GS, Fibiger HC (1992) Evidence for conditional neuronal activation following exposure to a cocaine-paired environment: role of forebrain limbic structures. J Neurosci 12:4112-4121.

Busch SJ, Sassone-Corsi P (1990) Dimers, leucine zippers and DNAbinding domains. Trends Genet 6:36-40.

Campeau S, Hayward MD, Hope BT, Rosen JB, Nestler EJ, Davis M (1991) Induction of the c-fos proto-oncogene in rat amygdala during unconditioned and conditioned fear. Brain Res 565:349-352.

Cohen DR, Ferreira PCP, Gentz R, Franza, R Jr, Curran T (1989) The product of a fos-related gene, fra-1, binds cooperatively to the AP- 1 site with Jun: transcription factor AP-1 is comprised of multiple protein complexes. Genes Dev 3:173-184.

Curran T, Gordon MB, Rubino KL, Sambucetti LC (1987) Isolation and characterization of the c-fos (rat) cDNA and analysis of posttranslational modification in vitro. Oncogene 2:79-84.

D'Mello SR, Heinrich G (1991) Structural and functional identifica- tion of regulatory regions and cis elements surrounding the nerve growth factor gene promoter. Mol Brain Res 11:255-264.

Dobner PR, Kislauskis E, Bullock BP (1992) Cooperative regulation of neurotensin/neuromedin N gene expression in PC12 cells involves AP-1 transcription factors. Ann NY Acad Sci 668:17-29.

Dobrzanski P, Noguchi T, Kovary K, Rizzo CA, Lazo PS, Bravo R (1991) Both products of the fos $\mathrm{B}$ gene, FosB and its short form, FosB/SF, are transcriptional activators in fibroblasts. Mol Cell Biol 11:5470-5478.

Graybiel AM, Moratella R, Robertson HA (1990) Amphetamine and cocaine induce drug-specific activation of the c-fos gene in striosomematrix compartments and limbic subdivisions of the striatum. Proc Natl Acad Sci USA 87:6912-6916.

Hope B, Kosofsky B, Hyman SE, Nestler EJ (1992) Regulation of immediate early gene expression and AP- 1 binding in the rat nucleus accumbens by chronic cocaine. Proc Natl Acad Sci USA 89:57645768.

Hope BT, Kel7 M, Nestler FJ (1993) Chronic FCS treatment induces long lasting AP1 complex containing novel Fos related proteins. Soc Neurosci Abstr 19:1747.

Hunter T, Karin M (1992) The regulation of transcription by phosphorylation. Cell 70:375-387.

Hyman SE, Nestler EJ (1993) The molecular foundations of psychiatry. Washington, DC: American Psychiatric Press

Kapur S, Austin MC, Underwood MD, Arango V, Mann JJ (1993) Electroconvulsive shock increases tyrosine hydroxylase and neuropeptide $\mathrm{Y}$ gene expression in the locus coeruleus. Mol Brain Res 18: $121-126$.

Koerner M, Rattner A, Mauxion F, Sen R, Citri Y (1989) A brainspecific transcription factor. Neuron 3:563-572.

Lerea LS, McNamara JO (1993) Ionotropic glutamate receptor subtypes activate c-fos transcription by distinct calcium-requiring intracellular signaling pathways. Neuron 10:31-41.

Leviel V, Fayada C, Guibert B, Chaminade M, Machek G, Mallet J, Faucon-Biguet N (1990) Short- and long-term alterations of gene expression in limbic structures by repeated electroconvulsive-induced seizures. J Neurochem 54:899-904.

Lin W-C, Desiderio S (1993) Regulation of V(D)J recombination activator protein RAG-2 by phosphorylation. Science 260:953-959.

Morgan JI, Curran T (1991) Stimulus-transcription coupling in the nervous system: involvement of the inducible proto-oncogenes fos and jun. Annu Rev Neurosci 14:421-451.

Mumberg D, Lucibello FC, Schuermann M, Muller R (1991) Alternative splicing of $f o s \mathrm{~B}$ transcripts results in differentially expressed mRNAs encoding functionally antagonistic proteins. Genes Dev 5:1212-1223

Nakabeppu Y, Ryder K, Nathans D (1988) DNA binding activities of three murine Jun proteins: stimulation by fos. Cell 55:907-915.

Naranjo JR, Mellstrom B, Achaval M, Sassone-Corsi P (1991) Molecular pathways of pain: Fos/Jun-mediated activation of a non-canonical AP-1 site in the prodynorphin gene. Neuron 6:607-617.

Nestler EJ, McMahon A, Sabban EL, Tallman JF, Duman RS (1990) Chronic antidepressant administration decreases the expression of tyrosine hydroxylase in the rat locus coeruleus. Proc Natl Acad Sci USA 87:7522-7526.

Ofir R, Dwarki VJ, Rashid D, Verma IM (1990) Phosphorylation of the $\mathrm{C}$ terminus of Fos protein is required for transcriptional transrepression of the c-fos promoter. Nature 348:80-82.

Papavassiliou AG, Treier M, Chavrier C, Bohmann D (1992) Targeted degradation of c-Fos, but not v-Fos, by a phosphorylation-dependent signal on c-Jun. Science 258:1941-1944.

Pennypacker KR, Zhang WQ, Ye H, Hong JS (1992) Apomorphine induction of AP-1 DNA binding in the rat striatum after dopamine depletion. Mol Brain Res 15:151-155.

Persico AM, Schindler CW, O’Hara BF, Brannock MT, Uhl GR (1993) Brain transcription factor expression: effects of acute and chronic amphetamine and injection stress. Mol Brain Res 20:91-100.

Sharp FR, Sagar SM, Hicks K, Lowenstein D, Hisanaga K (1991) cfos mRNA, Fos, and Fos-related antigen induction by hypertonic saline and stress. J Neurosci 11:2321-2331.

Shneidman PS, Bruce J, Schwartz ML, Schlaepfer WW (1992) Negative regulatory regions are present upstream in the three mouse neurofilament genes. Mol Brain Res 13:127-138.

Singh IS, Luo Z, Eng A, Erlichman J (1991) Molecular cloning and characterization of the promoter region of the mouse regulatory sub- 
unit RII $\beta$ of type II cAMP-dependent protein kinase. Biochem Biophys Res Commun 178:221-226.

Sonnenberg JL, Macgregor-Leon PF, Curran T, Morgan JI (1989) Dynamic alterations occur in the levels and composition of transcription factor AP-1 complexes after seizure. Neuron 3:359-365.

Taylor LK, Marshak DR, Landreth GE (1993) Identification of a nerve growth factor- and epidermal growth factor-regulated protein kinase that phosphorylates the protooncogene product c-Fos. Proc Natl Acad Sci USA 90:368-372.

Winston SM, Hayward MD, Nestler EJ, Duman RS (1990) Chronic electroconvulsive seizures down-regulate expression of the immedi- ate-early genes c-fos and c-jun in rat cerebral cortex. J Neurochem 54:1920-1925.

Yoon SO, Chikaraishi DM (1992) Tissue-specific transcription of the rat tyrosine hydroxylase gene requires synergy between an AP- 1 motif and an overlapping $\mathrm{E}$ box-containing dyad. Neuron 9:55-67.

Young S, Porrino LJ, Iadarola MJ (1991) Cocaine induces striatal c-Fos-immunoreactive proteins via dopaminergic $D_{1}$ receptors. Proc Natl Acad Sci USA 88:1291-1295.

Zhou Q-Y, Li C, Civelli O (1992) Characterization of gene organization and promoter region of the rat dopamine $\mathrm{D} 1$ receptor gene. $\mathrm{J}$ Neurochem 59:1875-1883. 